\title{
EDITORIAL
}

\section{The other side of the coin}

\author{
Ana Cecília Marques, ${ }^{1}$ Sérgio de Paula Ramos ${ }^{2,3}$ (DD \\ ${ }^{1}$ Universidade Federal de São Paulo (UNIFESP), São Paulo, SP, Brazil. ${ }^{2}$ Academia Sul-Rio-Grandense de Medicina, Porto Alegre, RS, Brazil. \\ ${ }^{3}$ Associação Brasileira de Estudos do Álcool e Outras Drogas (ABEAD), Brazil.
}

At a time when several countries have been discussing different degrees of cannabis liberalization, the work by Fischer et al. is timely. ${ }^{1}$ Furthermore, it has the merit of reviewing the acute and chronic effects of the use of cannabis, especially by young people. These findings are now corroborated by studies of population samples from childhood to adulthood; epidemiological series in different age groups within the same state or country; clinical cross-sectional studies; randomized double-blind clinical trials; and neuroimaging studies that have provided evidence of alterations in brain structure. ${ }^{2,3}$

On the other hand, the authors were not as attentive to the other side of the coin. The international machinations underlying the shift in attitudes toward cannabis that have been taking place worldwide must be analyzed: a "new" economic and social system made up of different cannabis interest groups has been working to expand its business, aiming at a consequent increase in profits and disregarding the impact of this phenomenon on public health and social stability, not to mention on the future of young people and the world economy itself. ${ }^{4}$

Almost a hundred years ago, the same process happened with tobacco. The similarity of the strategies used in relation to cannabis is notable. The tobacco industry claimed that smoking was good for bronchitis, sore throats, headaches, among other medical indications - marketed by doctors who had been hired for the sole purpose of lending credibility to the product, as if it were medication. Advertisements showed slender, rosy women, who in no way resembled actual smokers (neither in appearance nor in health), who, hypertensive and pale, would experience early mortality from myocardial infarction and cancer, as well as other widely studied comorbidities, including mental conditions. ${ }^{5}$

Among the several actions used to reduce society's perception of cannabis-related risks, especially among adolescents, the most frequent action is that of referring to "medical marijuana." There is in fact no evidence that, if smoked, this drug can produce any health benefits, even taking into account the few studies on cannabinoids conducted with any methodological rigor, or case studies on the use of the drug for multiple sclerosis, refractory epilepsy, anorexia due to chemotherapy, and chronic neuropathic pain. ${ }^{2}$ The aim of this action is to reduce the perception of risk, thereby increasing consumption.
Another point that is not addressed by the authors concerns what is happening in countries or states that have adopted more flexible measures regarding the use of cannabis and its derivatives. Epidemiological reports show an increase in consumption among 15-to-28 yearolds, precisely the age at which young people are healthiest, yet are also exposed to more serious consequences for mental, academic, and social health, as well as to a high prevalence of death from external causes. Crime has not declined in North American jurisdictions that have legalized cannabis (data on the state of Colorado, 5 years after legalization, are available from the Colorado Department of Investigation and the Federal Bureau of Investigation). ${ }^{6}$ News in the lay press reports that crime in Uruguay, which has also legalized cannabis, has actually increased.

Similarly, the authors overlook the sociocultural differences between Brazil and Canada. Brazil's economy is stagnant. It is a country of continental dimensions with no educational, social, or political stability. In addition, a drug policy has never been implemented, at least as far as prevention is concerned. This has resulted in a lack of control of the early use of licit drugs among adolescents, who engage in intoxication by multiple substances, both legal and illegal (including cannabis), as has been confirmed by epidemiological studies. One might ask: if the country cannot prevent children and adolescents from drinking and smoking, will it be able to discipline marijuana use?

Cannabis is the most consumed illicit drug in Brazil. Its use has been increasing, especially among adolescents. Publishing recommendations on how to handle "low-risk drugs" that state, from beginning to end, that cannabis is a low-risk drug when it is in fact known to be a highpotency drug is to lay yet another trap as those that have been so well described throughout the history of humankind and drugs. Outcomes have been proven to be 1) an increase in consumption, especially by vulnerable populations ${ }^{7,8}$; 2) no decline in imprisonment rates, regardless of ethnicity and socioeconomic class ${ }^{9,10}$; 3 ) the discovery, a posteriori, of serious health effects, both to users and to the fetus ${ }^{11-13}$; and 4) that, in face of such a complex phenomenon, policies have not prevented impacts on individuals and families, neither in Brazil nor elsewhere in the world. 
It is for all these reasons that it is recommended that before any partial action related to this topic is replicated in Brazil, an in-depth analysis of the geopolitics of drugs should be carried out, endeavoring to resist the pressure of the economic and social system involving cannabis and to contribute to ensure it is not legalized.

\section{Disclosure}

The authors report no conflicts of interest.

\section{References}

1 Fischer B, Malta M, Messas G, Ribeiro M. Introducing the evidencebased population health tool of the Lower-Risk Cannabis Use Guidelines to Brazil. Braz J Psychiatry. 2019;41:550-5.

2 World Health Organization (WHO). (2016). The health and social effects of nonmedical cannabis use [Internet]. 2016 [cited 2019 Sep 10]. www.who.int/substance_abuse/publications/msbcan nabis.pdf

3 Batalla A, Bhattacharyya S, Yücel M, Fusar-Poli P, Crippa JA, Nogué $S$, et al. Structural and functional imaging studies in chronic cannabis users: a systematic review of adolescent and adult findings. PLoS One. 2013;8:e55821.

4 Degenhardt L, Ferrari AJ, Calabria B, Hall WD, Norman R, McGrath $J$, et al. The global epidemiology and contribution of cannabis use and dependence to the global burden of disease: results from the GBD 2010 Study. PLoS One. 2013;8:e76635.
5 World Health Organization (WHO). WHO global report on trends in prevalence of tobacco smoking 2000-2025 - second edition. Geneva: WHO; 2018.

6 United Nations (UN), Commission on Crime Prevention and Criminal Justice. World crime trends and emerging issues and responses in the field of crime prevention and criminal justice [Internet]. 2017 Mar 7 [cited 2019 Sep 10]. www.unodc.org/documents/data-and-analysis/ statistics/crime/ccpj/World crime trends emerging issues E.pdf

7 Melchior M, Nakamura A, Bolze C, Hausfater F, El Khoury F, MaryKrause $M$, et al. Does liberalization of cannabis policy influence levels of use in adolescents and young adults? A systematic review and meta-analysis. BMJ Open. 2019;9:e025880.

8 United Nations Office on Drugs and Crime (UNODC). World Drug Report 2019. 5 Cannabis and hallucinogens [Internet]. 2019 [cited 2019 Nov 5]. wdr.unodc.org/wdr2019/prelaunch/WDR19_Booklet_5_ CANNABIS_HALLUCINOGENS.pdf

9 World Health Organization (WHO). Cannabis: the health and social effects of nonmedical cannabis use [Internet]. 2016 [cited 2019 Nov 5]. who.int/substance_abuse/publications/msbcannabis.pdf

10 United Nations Office on Drugs and Crime (UNODC). World Drug Report 2019. 1 Executive summary [Internet]. 2019 [cited 2019 Nov 5]. wdr.unodc.org/wdr2019/prelaunch/WDR19_Booklet_1_EXECUTIVE_ SUMMARY.pdf

11 Goldschmidt L1, Day NL, Richardson GA. Effects of prenatal marijuana exposure on child behavior problems at age 10. Neurotoxicol Teratol. 2000;22:325-36.

12 Forrester MB, Merz RD. Risk of selected birth defects with prenatal illicit drug use, Hawaii, 1986-2002. J Toxicol Environ Health A. 2007; 70:7-18.

13 Van Gelder MM, Reefhuis J, Caton AR, Werler MM, Druschel CM, Roeleveld N, et al. Maternal periconceptional illicit drug use and the risk of congenital malformations. Epidemiology. 2009;20:60-6. 